\title{
Comparison of models for estimating bark thickness of Picea abies in southwest Germany: the role of tree, stand, and environmental factors
}

\author{
Stefan M. Stängle ${ }^{1}$ Udo H. Sauter ${ }^{1}$ - Carsten F. Dormann ${ }^{2}$
}

Received: 29 June 2016 / Accepted: 4 November 2016/Published online: 15 February 2017

(C) INRA and Springer-Verlag France 2017

\begin{abstract}
- Key message Bark thickness was shown to vary between regions, stands, and trees. Bark thickness prediction equations of different model complexity can be suggested depending on the purpose of application. Site and stand conditions, which influence variation of growth rate to a large extent, seem to have a strong influence on bark thickness, with better site quality leading to smaller relative bark thickness.

- Context For many applications in forestry and forest science, local or regional species-specific bark thickness equations are used to estimate inside-bark diameters with outsidebark diameter measurements.

- Aims The objectives of this study were (1) to assess variation in bark thickness due to tree and stand factors in two

Handling Editor: Marcus SCHAUB

Contribution of the co-authors S. Stängle did the field work, performed the data analysis, and wrote the manuscript; U. Sauter coordinated the research project and reviewed and commented on successive drafts of the manuscript; and C. Dormann supervised the study and reviewed and commented on successive drafts of the manuscript.
\end{abstract}

Stefan M. Stängle

stefan.staengle@forst.bwl.de

Udo H. Sauter

udo.sauter@forst.bwl.de

Carsten F. Dormann

carsten.dormann@biom.uni-freiburg.de

1 Forest Research Institute Baden-Württemberg, Wonnhaldestr. 4, 79100 Freiburg, Germany

2 Biometry and Environmental System Analysis, University of Freiburg, Tennenbacher Str. 4, 79106 Freiburg, Germany
Norway spruce (Picea abies (L.) Karst) datasets from different time periods, (2) to compare and evaluate alternative established model forms for estimating bark thickness, and (3) to assess spatial variation in bark thickness to estimate the effects of environmental factors on bark thickness.

- Methods Different bark thickness models were chosen from the literature and compared for their predictive quality for new measurements and a dataset from the 1970s. Mixed-effect modelling was applied to account for the hierarchical data structure, and generalized additive mixed models were used to analyse spatial effects and the influence of climatic factors, such as precipitation and temperature.

- Results A strong positional autocorrelation of bark thickness within trees and within plots could be shown. Bark thickness was smaller in the new data compared to the measurements from the 1970s. The variation between stands could not be explained by the tested environmental factors, but tree age had a strong positive effect on bark thickness.

- Conclusion In the study region, the variation of site productivity and individual growth rate seem to have a strong influence on bark thickness, whereas no significant effect of large scale climatic factors could be found.

Keywords Norway spruce - Linear mixed-effects models · Nonlinear mixed-effects models · Generalized additive mixed models $\cdot$ Allometric equations $\cdot$ Growth rate $\cdot$ Climatic effects

\section{Introduction}

Although tree and log diameters are usually measured outside bark, for many applications in forestry and forest science, diameters inside bark are more important. Diameters inside bark are used to calculate wood volume of logs or trees for trade and forest inventories, and also, bucking optimization 
software in harvesters depends on them. To convert outsidebark diameters to inside-bark diameters, bark thickness equations have been developed for many species in the last decades (e.g. Li and Weiskittel 2011). These can also be used to calculate bark volume, which increasingly gained interest with the shift in the commercial relevance of bark from an unwanted residue to a valuable fuel and a source for high-value biomaterials (Doruska et al. 2009). The prediction of available bark biomass is important to assess the potential of such technologies generating potential additional income for the forestry sector. Another important application for bark thickness estimates is growth and increment predictions that are based on outside-bark measurements.

A common definition of bark, which we also used in this study, includes all tissues outside the vascular cambium and comprises secondary phloem up to the last-formed periderm and the rhytidome, which comprises all layers of dead tissue outside of the currently active periderm (Martin and Christ 1970). Bark development depends on two lateral meristems: the vascular cambium, which forms the phloem, and the phellogen (cork cambium) in each periderm, which forms phelloderm to the inside and phellem (cork) to the outside (Evert 2009).

The first studies on bark thickness and bark volume in central Europe were performed in the late nineteenth century in Switzerland to develop conversion factors from log volume with bark to log volume without bark. This research by Flury (1897) was the beginning of still ongoing research on the development of bark equations for many species in many parts of the world. Bark thickness equations have been developed from simple linear regression models that predict the percentage of bark with only diameter measurements (e.g. Flury 1897) to more elaborate model forms that describe the bark thickness as a function of several predictor variables that are usually easy to asses on the stem. The coefficients of such equations are usually valid for one species for a certain region. For many coniferous species, it has been shown that bark thickness can be well described by tree-inherent variables, such as diameter outside bark, total tree height, and height of the measurement position (e.g. Li and Weiskittel 2011). For Norway spruce (Picea abies (L.) Karst), it has been shown that bark thickness increases with diameter outside bark and with relative tree height and is influenced by tree age, tree height, and tree form (Laasasenaho et al. 2005).

Numeral external factors that correlate with bark percentage of trees have been reported, and many of them can be interpreted in a way that slower tree growth leads to larger relative bark thickness, as the following examples illustrate. For Pinus sylvestris (L.), the latitude of forest stands, which mainly describes differences in temperature and the length of the growing season, could help explaining bark thickness variation (Wilhelmsson et al. 2002). A correlation between a low site index or yield class of stands and a larger relative bark thickness was shown for Norway spruce (Dimitrov 1976; Hoffmann 1958; Schmidt-Vogt 1986) and silver fir (Abies alba Mill.) (Božić et al. 2007). Sonmez et al. (2007) reported a positive effect of tree age on bark thickness for Picea orientalis (L.) Link. Contrasting results were reported for the broadleaved Nothofagus pumilio (Poepp. and Endl.) Krasser by Cellini et al. (2012), where relative bark thickness was lower on low-productivity sites.

Besides growth conditions, also, genetics can determine bark thickness. Provenance has been shown to influence the phenotypic development of bark thickness of Pinus contorta var. latifolia Engelm. (Persson and Downie 1992) and Pseudotsuga menziesii (Mirb.) Franco (Kohnle et al. 2012).

In this study, we focus on Norway spruce in central Europe. Measurements in the state of Baden-Württemberg, southwest Germany, in the 1970s revealed a spatial heterogeneity of spruce bark thickness in that region (Altherr et al. 1978). Silvicultural practices have changed in the study region within the last decades with trees planted at wider initial spacing and earlier thinning being performed. Additionally, more forests have been converted to uneven-aged or mixed-species stands. Changes in silviculture, changed climatic conditions, and increased nitrogen emissions altered tree growth trends within the last century in the study area (e.g. Yue et al. 2011) and potentially also changed the relation between diameter increment and bark development. Advanced technology for data processing and modelling is available today and allows us to compare the correlation structure within bark thickness data from the 1970s and the 2010s and analyse the new data for potential factors influencing bark thickness development.

The objectives of this study were to:

1. Assess variation in bark thickness due to tree and stand factors in two Norway spruce datasets from different time periods

2. Compare and evaluate alternative established model forms for estimating bark thickness

3. Assess the spatial variation in bark thickness to estimate the effects of environmental factors on bark thickness.

\section{Material and methods}

\subsection{Data origin}

Bark thickness data were obtained from two sources: an extensive dataset with 7712 trees from Altherr et al. (1978) and a smaller set with 508 trees from measurements acquired between 2014 and 2016. Dimensional details are listed in Table 1. Trees of both datasets were sampled throughout the $35,752-\mathrm{km}^{2}$ state of Baden-Württemberg in temperate forests with a broad range of site and stand conditions. For the new 
Table 1 Characteristics of the measured trees from datasets 1 and 2: diameter at breast height (dbh), double bark thickness at breast height $\left(\mathrm{DBT}_{1.3}\right)$, the total tree height, and age. Dataset 1 is from Altherr et al. (1978)

\begin{tabular}{|c|c|c|c|c|c|c|c|c|}
\hline & \multicolumn{4}{|c|}{ Dataset 1 (1970s) } & \multicolumn{4}{|c|}{ Dataset $2(2014-2016)$} \\
\hline & Mean & $\mathrm{SD}$ & Minimum & Maximum & Mean & $\mathrm{SD}$ & Minimum & Maximum \\
\hline $\mathrm{dbh}(\mathrm{cm})$ & 34.5 & 14.5 & 13.1 & 84.6 & 39.8 & 11.3 & 17.3 & 81.5 \\
\hline $\mathrm{DBT}_{1.3}(\mathrm{~mm})$ & 19.1 & 6.4 & 6.0 & 48.0 & 20.1 & 6.0 & 7.0 & 46.0 \\
\hline Tree height (m) & & & & & 29.6 & 4.2 & 14.6 & 44.3 \\
\hline Age $(a)$ & & & & & 86.4 & 28.2 & 32 & 216 \\
\hline
\end{tabular}

$S D$ standard deviation

data, 508 trees were selected for measurements in 35 plots, covering the major growth regions within the state (Fig. 1). Elevation of the plots varied between 277 and $1219 \mathrm{~m}$ above sea level. Mean annual air temperature varied between 4.6 and $9.3{ }^{\circ} \mathrm{C}$ and annual precipitation sum between 806 and $1945 \mathrm{~mm}$ year $^{-1}$. Mixed-species stands and pure spruce stands were chosen, and trees from thinning operations as well as from final harvest in selection-cutting systems were chosen. Sample size for plots and trees per plot was chosen after the variation in the Altherr et al. (1978) data had been assessed by Stängle et al. (2016).

\subsection{Measurements}

The sampling for both datasets was performed as described by Altherr et al. (1974, 1978): trees were felled, delimbed, and measured in the forest before any further log manipulation was performed. Measurement locations were at breast height (1.3 $\mathrm{m}$ above ground) and along the tree bole in 2-m increments up to a top diameter of approximately $10-15 \mathrm{~cm}$. This distribution of locations within trees was shown to be adequate to describe within-tree variability within the merchantable bole length above $1.3 \mathrm{~m}$ (Stängle et al. 2016). Variability of bark thickness below $1.3 \mathrm{~m}$ could, however, significantly increase due to changes in stem form and bark profiles.
Diameter and bark thickness were measured twice (approximately perpendicularly) at each location using both a calliper and a Swedish bark gauge, respectively. Double bark thickness was calculated as the sum of the two bark measurements. Additional measurements for the new data were tree height, which was measured on the felled tree, and tree age. Tree height for the Altherr et al. (1978) data was modelled with mixed B-spline regression describing tree taper using the R package TapeR (Kublin and Breidenbach 2013).

\subsection{Variability between stands and trees}

Due to the nested sampling design, bark thickness measurements display similarity of measurements within each tree and within plots (e.g. Li and Weiskittel 2011). If the variance between groups (such as trees and plots in our case) is large, additional information on group-level predictors could explain this variance. The between-group variance can be expressed by the intraclass correlation coefficient (Schielzeth and Nakagawa 2013). Variance components of two linear bark thickness models of different complexity (see below) were analysed, and the intraclass correlation coefficients were calculated as the ratio of between-group variances to total residual variance. Depending on model form and the included covariates, intraclass correlation can differ substantially for the
Fig. 1 Distribution of the sample plots of dataset 2. Sampling of dataset 1 was performed in the same area (plots not shown)

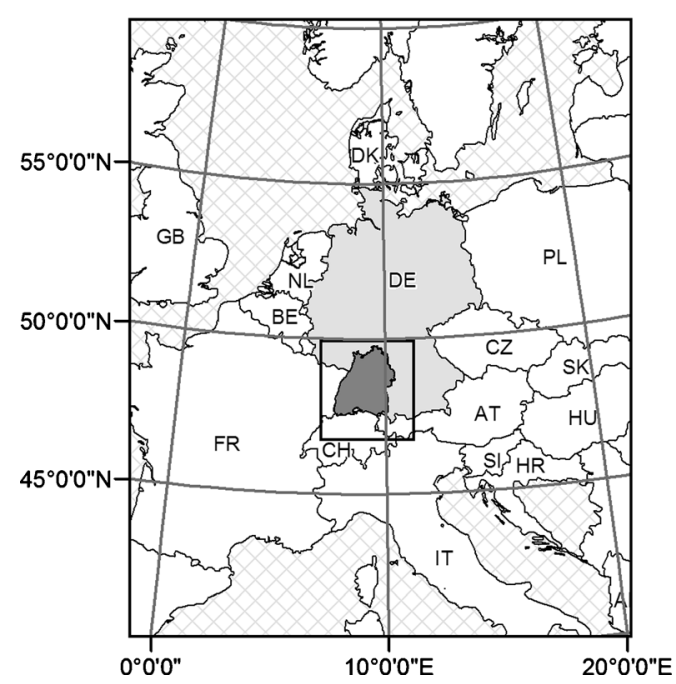


same data (e.g. Stängle et al. 2016). Equations (1) and (2) were chosen from the literature as both are established model forms for predicting bark thickness. Equation (1) was introduced by Loetsch et al. (1973) and was used by Zacco (1974) for Sweden and was suggested as useful for spruce species by Li and Weiskittel (2011, eqn 7). Equation (2) was introduced by Hannrup (2004) and is implemented in the harvester protocol Standard for Forest Data and Communication StanForD (Skogforsk 2012). Double bark thickness is predicted in the two linear models as follows:

$$
\begin{aligned}
& D B T=\beta_{0}+\beta_{1} d_{\mathrm{ob}}+\varepsilon \\
& D B T=\beta_{0}+\beta_{1} d b h_{\mathrm{ob}}+\beta_{2} d_{\mathrm{ob}}+\varepsilon
\end{aligned}
$$

where $D B T$ is the double bark thickness at any point of the stem $(\mathrm{mm}), d_{\mathrm{ob}}$ is the diameter outside bark at that position $(\mathrm{mm}), d b h_{\mathrm{ob}}$ is the diameter outside bark at breast height (1.3 $\mathrm{m}$ height) $(\mathrm{mm}), \varepsilon$ is the residual of the model, and $\beta_{0}, \beta_{1}$, and $\beta_{2}$ are the regression coefficients.

\subsection{Model comparison}

Six different model forms were compared for their fit quality and their predictive capacity for both datasets. To account for the hierarchical data structure, we applied mixedeffect modelling with random deviation of the intercept on the tree and the plot levels, leading to Eqs. (3), (4), (5), (6), (7), and (8):

$$
\begin{aligned}
& D B T=\beta_{0}+\beta_{1} d_{\mathrm{ob}}+b_{i}+b_{i j}+\varepsilon_{i j k} \\
& \begin{aligned}
D B T=\beta_{0} & +\beta_{1} d b h_{\mathrm{ob}}+\beta_{2} d_{\mathrm{ob}}+b_{i}+b_{i j}+\varepsilon_{i j k} \\
\log (D B T)= & \beta_{0}+\beta_{1} d_{\mathrm{ob}}+\beta_{2} \log d_{\mathrm{ob}}+\beta_{3} \operatorname{ind}_{d b h}+b_{i} \\
& +b_{i j}+\varepsilon_{i j k} \\
D B T= & d_{\mathrm{ob}}\left(\beta_{1}+\beta_{2} \frac{h}{H}+\beta_{3}\left(\frac{h}{H}\right)^{2}+\beta_{4} H\right)+b_{i}+b_{i j} \\
& +\varepsilon_{i j k}
\end{aligned}
\end{aligned}
$$

$$
D B T=\beta_{0}+\beta_{1} d_{\mathrm{ob}}+\beta_{2} d_{\mathrm{ob}}{ }^{2}+\beta_{3} d_{\mathrm{ob}}{ }^{3}+b_{i}+b_{i j}+\varepsilon_{i j k}
$$

$$
\begin{aligned}
\log \left(D B T / d_{\mathrm{ob}}\right)= & \beta_{0}+\beta_{1}\left(1-\frac{h}{H}\right)^{\beta_{2}}+\beta_{3}\left(\frac{h}{H}\right)^{\beta_{4} H} \\
& +\beta_{5} d b h_{\mathrm{ob}}+\beta_{6} \frac{H}{d b h_{\mathrm{ob}}}+b_{i}+b_{i j}+\varepsilon_{i j k}(8)
\end{aligned}
$$

where ind $_{d b h}$ is an indicator for breast height (if true $=1$; else $=0$ ), $h$ is the height above ground at the measurement point along the bole (m), $H$ is the total tree height (m), $b_{i}$ is the random effect for the $i$ th plot, $b_{i j}$ is the random effect for the $j$ th tree in plot $i, \varepsilon_{i j k}$ is the residual error for the $k$ th measurement in the $j$ th tree in plot $i, \beta_{0-6}$ are the regression coefficients, and other variables are defined as above.

Equations (3) and (4) correspond to Eqs. (1) and (2), respectively, with the additional random effect terms. Equation (5) was found to be suitable for spruce by Wilhelmsson et al. (2002, eqn S5b), and Eq. (6) was introduced by Cao and Pepper (1986, eqn 4) and suggested by Li and Weiskittel (2011, eqn 4). Model forms of Eqs. (7) and (8) were described by Gordon (1983, eqs 9 and 3). The dependent variable of Eqs. (5), (6), and (7) in the original publications was the diameter inside bark and was changed for this study, so that predictions were made for double bark thickness for Eqs. (3), (4), (5), (6), and (7).

To account for positional autocorrelation within each tree, which was not eliminated by introducing the tree-level random effect, a first-order continuous autoregressive correlation structure (CAR1) was applied (Pinheiro and Bates 2000), which has widely been used in forestry (Weiskittel et al. 2011). This accounts for the similarity of bark thickness values within the tree along the stem, with closer positions being more similar to each other. A power variance function with $d_{\mathrm{ob}}$ as covariate was introduced to account for a larger residual spread for increasing diameters. Previous analyses showed correlated errors and heteroscedastic errors in the data and led us to introduce the above-described within-group correlation structure and within-group heteroscedasticity structure. Bayesian information criterion (BIC) was computed to quantify an improvement of the model fit by introducing those structures.

Fit statistics include mean absolute error (MAE) and root mean square error (RMSE). Fits of the models (6) and (8) were corrected after logarithmic back-transformation (Baskerville 1972; Sprugel 1983). For the evaluation of the predictive capacity of the models, tenfold block cross-validation was performed. Therefore, the data was randomly split in ten subsamples with each of them containing the same number of plots. In each of ten runs, one subsample was used as validation data and the remaining nine subsamples as training data. Results from all runs were averaged. Mixed model fitting was performed using the lme function of the package nlme (Pinheiro et al. 2016) in the software R version 3.2.2 ( $\mathrm{R}$ Core Team 2015).

To check if the two datasets led to significantly different parameter estimates, the best-fitting model (8) was fit to both datasets separately. Residuals from both fits were compared with equivalence testing to see whether the model form could describe both datasets similarly well. Subsequently, both models were applied to calculate double bark thickness 
predictions for the new dataset and results were compared with equivalence testing. For both equivalence tests, the region of indifference was set to $0.5 \mathrm{~mm}$, which defines the absolute size that the mean of the differences can reach so that $\mathrm{H}_{0}$ is still rejected, and therefore, equivalence is assumed (Robinson and Froese 2004). The R package equivalence (Robinson 2016) was used to calculate a robust two onesided $t$ test (TOST) for equivalence of unpaired data for the residuals and for paired data for the bark thickness predictions, respectively.

\subsection{Spatial variation of bark thickness}

In the last step of this study, we tried to interpret the variation in bark thickness between stands, which could be caused by environmental factors. As exact stand position and tree age were only known for the newly collected data, this step could only be performed for dataset 2 . To account for climatic effects, we included annual precipitation $\left(\mathrm{mm} \mathrm{year}^{-1}\right)$ and mean annual air temperature $\left({ }^{\circ} \mathrm{C}\right)$. The elevation of the sample plots (metres above sea level) and geographic coordinates (GaussKrüger projection, in $\mathrm{m}$ ) were included to evaluate spatial effects that could be explained by climatic as well as by biotic or abiotic factors such as site index and soil materials, respectively. Additionally, we included tree age to account for growth rate of the single trees, which can be influenced by site quality and tree individual factors, such as suppression in their early growth phase by larger trees. Generalized additive mixed models (GAMMs) were chosen for this analysis, and predictor variables were introduced as thin-plate regression splines with the R package mgcv (Wood 2011). Geographic coordinates were introduced as tensor product splines to model a two-dimensional surface as suggested in Wood (2006). To account for positional autocorrelation within each tree, a firstorder continuous autoregressive correlation structure (CAR1) was applied (Pinheiro and Bates 2000). The model had the following form:

$$
\begin{aligned}
D B T= & \beta+f_{s}\left(d_{\mathrm{ob}}\right)+f_{s}\left(d b h_{\mathrm{ob}}\right)+f_{s}(H)+f_{s}\left(\frac{h}{H}\right) \\
& +f_{s}(\text { age })+f_{\text {te }}(X \text { coord }, Y \text { coord })+f_{s}(\text { elev. }) \\
& +f_{s}(\text { prec })+f_{s}(\text { temp. })+b_{i}+b_{i j}+\varepsilon_{i j k}
\end{aligned}
$$

where $f_{s}\left(d_{\mathrm{ob}}\right), f_{s}\left(d b h_{\mathrm{ob}}\right), f_{s}(H), f_{s}\left(\frac{h}{H}\right), f_{s}(\mathrm{age}), f_{s}(\mathrm{elev}),. f_{s}$ (prec.), and $f_{s}$ (temp.) are smooth functions of $d_{\mathrm{ob}}, d b h_{\mathrm{ob}}, H, \frac{h}{H}$, tree age (years), elevation, annual precipitation, and mean annual air temperature; $f_{t e}(X$ coord, $Y$ coord $)$ is a tensor product spline of geographic coordinates; $b_{i}$ is the random effect of the $i$ th plot, $b_{i j}$ is the random effect for $j$ th tree in plot $i$, and $\varepsilon_{i j k}$ is the residual error for the $k$ th measurement in the $j$ th tree in plot $i$.
Fit statistics of submodels of Eq. (9) were compared after dropping single explanatory variables using the dredge function of the MuMIn package (Barton 2016) to test significance of each model parameter. BIC was computed to rank the fits achieved by this procedure.

\section{Results}

\subsection{Variability between stands and trees}

For both datasets, a strong positional autocorrelation of bark thickness within trees and within plots could be shown. Total residual variance was similar between the two datasets (old and new data) and was lower for Eq. (2), which had one more predictor variable than Eq. (1) (Table 2). Differences in the correlation structure of the two datasets could be shown, as the largest proportion of variability was found between the plots in dataset 1 and between the trees in dataset 2 . The intraclass correlation at the plot level in the old data was approximately twice as high as in the new data, which means that the variability within plots, and therefore between trees, was much lower in the old data. The within-tree variability was higher in the old dataset, which was indicated by a lower intraclass correlation coefficient at the tree level.

\subsection{Model evaluation}

Fit statistics revealed that Eq. (5), which included $d_{\mathrm{ob}}$ and $\operatorname{ind}_{d b h}$ as predictor variables, performed best for model fitting, but generally worst in the validation process (Table 3). For prediction purposes, the nonlinear model form (Eq. (8)), which included $d_{\mathrm{ob}}, d b h_{\mathrm{ob}}, \frac{h}{H}$, and $H$, was found to be the best model for both datasets. Equation (3) that only used the diameter outside bark as prediction variable was found to perform worse than Eq. (4), which included also the diameter at breast height. Parameter estimates of all models can be found in Table 4.

Fitting model (8) on both datasets separately led to equivalent prediction bias $(p<0.05$, region of equivalence $0.5 \mathrm{~mm}$ ), leading to the assumption that the model could describe both datasets equally well. However, predictions for the newly assessed data were significantly higher $(p<0.05$, region of equivalence $0.5 \mathrm{~mm}$ ), when the model had been fit on dataset 1 compared to predictions made with a model fit from dataset 2 (Fig. 2). Inverting the TOST revealed that a region of equivalence of at least $2.9 \mathrm{~mm}$ would have to be chosen, to assume equivalence of the bark thickness predictions made with equations that had been fit on the two datasets separately. 
Table 2 Correlation structure of both datasets expressed by total residual variance and variances between plots, between trees, and within trees for the two tested models

\begin{tabular}{lllrlll}
\hline Dataset & Equation & $\begin{array}{l}\text { Predictor } \\
\text { variables }\end{array}$ & $\hat{\sigma}_{\text {total }}^{2}$ & $\frac{\dot{\sigma}_{\text {plot }}^{2}}{\hat{\sigma}_{\text {total }}^{2}}(\%)$ & $\frac{\dot{\sigma}_{\text {tree }}^{2}}{\hat{\sigma}_{\text {total }}^{2}}(\%)$ & $\frac{\hat{\sigma}_{\varepsilon}^{2}}{\hat{\sigma}_{\text {total }}^{2}}(\%)$ \\
\hline $1(1970 \mathrm{~s})$ & $(1)$ & $d_{\mathrm{ob}}$ & 10.51 & 46.91 & 18.56 & 34.53 \\
& $(2)$ & $d_{\mathrm{ob}}, d b h_{\mathrm{ob}}$ & 8.71 & 49.82 & 22.79 & 27.39 \\
$2(2014-2016)$ & $(1)$ & $d_{\mathrm{ob}}$ & 12.37 & 28.76 & 35.54 & 35.70 \\
& $(2)$ & $d_{\mathrm{ob}}, d b h_{\mathrm{ob}}$ & 9.73 & 20.72 & 44.47 & 34.81 \\
\hline
\end{tabular}

$d_{\mathrm{ob}}$ is the diameter outside bark, $d b h_{\mathrm{ob}}$ is the diameter outside bark at breast height, $\hat{\sigma}^{2}$ total is the total residual variance, $\hat{\sigma}^{2}$ plot is the variance between plots, $\hat{\sigma}_{\text {tree }}^{2}$ is the variance between trees, and $\hat{\sigma}_{\varepsilon}^{2}$ is the variance within trees

\subsection{Spatial effects}

The GAMM fitting of Eq. (9) and its submodels obtained the best fit (assessed with BIC) when only the treeinherent predictors $d_{\mathrm{ob}}, d b h_{\mathrm{ob}}, \frac{h}{H}, H$, and age were included. Geographic coordinates and the climatic factors could not significantly contribute in explaining the variation. Estimated effects of the tested explanatory variables on double bark thickness can be interpreted with their smooth curves, where each curve illustrates the partial effect for each variable on double bark thickness, which is the sum of all effects. The effect of diameter outside bark on double bark thickness increased almost in a linear pattern (Fig. 3a). The effect of diameter at breast height increased over the full range of measured trees (Fig. 3b). The effect of tree height decreased linearly (Fig. 3c). The relative height showed almost no effect in the region of $10 \%$ relative tree height; however, a strong positive effect below and a slightly increasing effect above $10 \%$ could be observed (Fig. 3d). The effect of age clearly showed thicker bark at higher tree age (Fig. 3e). Diameter at breast height naturally increases with age. The increasing effects of diameter at breast height and age could therefore, at least partially, be caused by collinearity. Figure 4 , however, shows that both variables have positive effects on the bark thickness prediction at the same time, meaning that bark thickness in trees of the same dimension was higher when the trees were older.

\section{Discussion}

The two analysed datasets showed clear differences, with dataset 1 from Altherr et al. (1978) having higher bark thickness in general and more variability between different plots and within trees. We attribute those differences in the correlation structure to a lack of standardisation of the measurement procedure for dataset 1 , as the Swedish gauge is very sensitive to differences in pressure (Gray 1956; Mesavage 1969). For those measurements, different personnel was used for different plots, whereas the new measurements for dataset 2 were all made by the same operator. Other influencing factors might be sampling season, which was almost exclusively out of growth season for the new data and could not be reconstructed for the old data. Also, we tried to sample a possibly large range of tree diameters in each plot in the new data, which might have

Table 3 Summary of fit statistics of mixed-effect models (3)-(8) and the respective prediction bias using only the fixed terms for validation. The best values per dataset are set in italics

\begin{tabular}{|c|c|c|c|c|c|c|c|c|}
\hline \multicolumn{3}{|l|}{ Dataset } & \multirow{2}{*}{$\begin{array}{l}\text { Eq. (3) } \\
\text { LME } \\
1.87\end{array}$} & \multirow{2}{*}{$\begin{array}{l}\text { Eq. (4) } \\
\text { LME }\end{array}$} & \multirow{2}{*}{$\begin{array}{l}\begin{array}{l}\text { Eq. (5) } \\
\text { LME }\end{array} \\
1.01\end{array}$} & \multirow{2}{*}{$\begin{array}{l}\text { Eq. (6) } \\
\text { LME }\end{array}$} & \multirow{2}{*}{$\begin{array}{l}\text { Eq. (7) } \\
\text { LME } \\
1.85\end{array}$} & \multirow{2}{*}{$\begin{array}{l}\text { Eq. (8) } \\
\text { NLME } \\
1.14\end{array}$} \\
\hline $1(1970 s)$ & Fitting & $\operatorname{MAE}(\mathrm{mm})$ & & & & & & \\
\hline & & RMSE (mm) & 2.44 & 2.35 & 1.34 & 2.14 & 2.42 & 1.52 \\
\hline & Validation (10-fold CV) & MAE (mm) & 2.56 & 2.34 & 3.08 & 2.92 & 2.58 & 2.22 \\
\hline & & RMSE (mm) & 3.17 & 3.07 & 4.04 & 3.78 & 3.29 & 2.94 \\
\hline \multirow[t]{4}{*}{$2(2014-16)$} & Fitting & MAE (mm) & 1.91 & 1.95 & 1.20 & 1.44 & 1.98 & 1.26 \\
\hline & & RMSE (mm) & 2.48 & 2.55 & 1.57 & 1.95 & 2.61 & 1.68 \\
\hline & Validation (10-fold CV) & MAE (mm) & 3.03 & 2.58 & 3.28 & 2.62 & 2.98 & 2.39 \\
\hline & & RMSE (mm) & 3.75 & 3.31 & 4.19 & 3.42 & 3.69 & 3.14 \\
\hline
\end{tabular}

$L M E$ linear mixed-effects model, $N L M E$ nonlinear mixed-effects model, MAE mean absolute error, RMSE root mean square error 
reduced similarity of measurements within plots and, therefore, reduced the part of the variation that could be explained by the nesting in plots.

Results showed a complex nonlinear model (Eq. (8)) to be the best model for bark thickness prediction. This model cannot be suggested for all applications, though. Depending on the purpose of application, different explanatory variables are available and different degrees of computational complexity are reasonable. If bark thickness is to be modelled for inventory data, for example, a complex model with many explanatory variables, such as Eq. (8), can be suggested because taper curves outside bark are often available. If total and relative tree heights are not known, as in the situation when a harvester measures a tree, the best possible model without these covariates should be selected (Eq. (3)).

Differences in bark thickness development between trees of different seed source origin have been shown by Kohnle et al. (2012) and Persson and Downie (1992), however could not be reflected in this study. Most Norway spruce stands in southwest Germany were planted, but the origin of the seeds or the reproductive material was often unknown or not documented (Hosius et al. 2006; Konnert 1991).

The bark thickness variation that was found between the plots in this study could not be linked to large-scale spatial patterns, such as climatic zones, because geographic coordinates did not explain the variation to a significant amount. Also, the climatic factors temperature and precipitation could not explain differences between plots. Age, however, was found to have a significant positive effect on bark thickness. These findings are in accordance with findings of Laasasenaho et al. (2005) and Sonmez et al. (2007). This leads to the conclusion that faster tree growth results in smaller relative bark thickness for Norway spruce. Increased site quality, which usually can be linked to faster growth of individual trees, was shown to reduce bark thickness also in other studies (Božić et al. 2007; Dimitrov 1976; Hoffmann 1958; Schmidt-

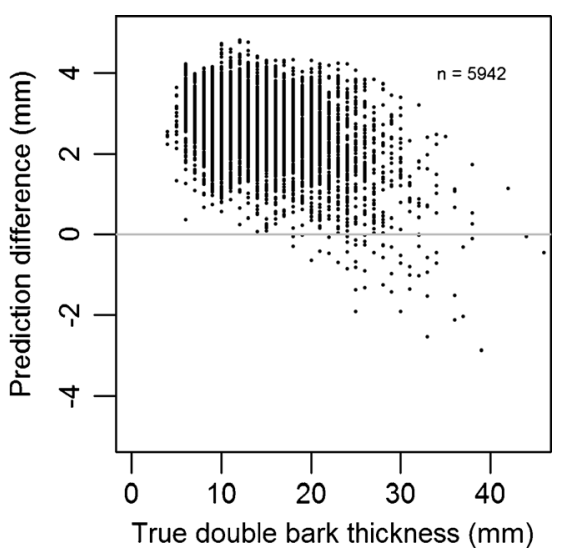

Fig. 2 Difference in double bark thickness predictions gained with two fits of Eq. (8): one fit on the Altherr et al. (1978) data (dataset 1) and one fit on the newly collected data of this study (dataset 2) 
Fig. 3 Estimated smooth functions describing the partial effect of the five covariates on double bark thickness (DBT): a) the smooth of diameter outside bark, (b) the smooth of dbh outside bark, (c) the smooth of tree height, (d) the smooth of relative tree height, and (e) the smooth of age. Shaded areas are 95\%-confidence intervals
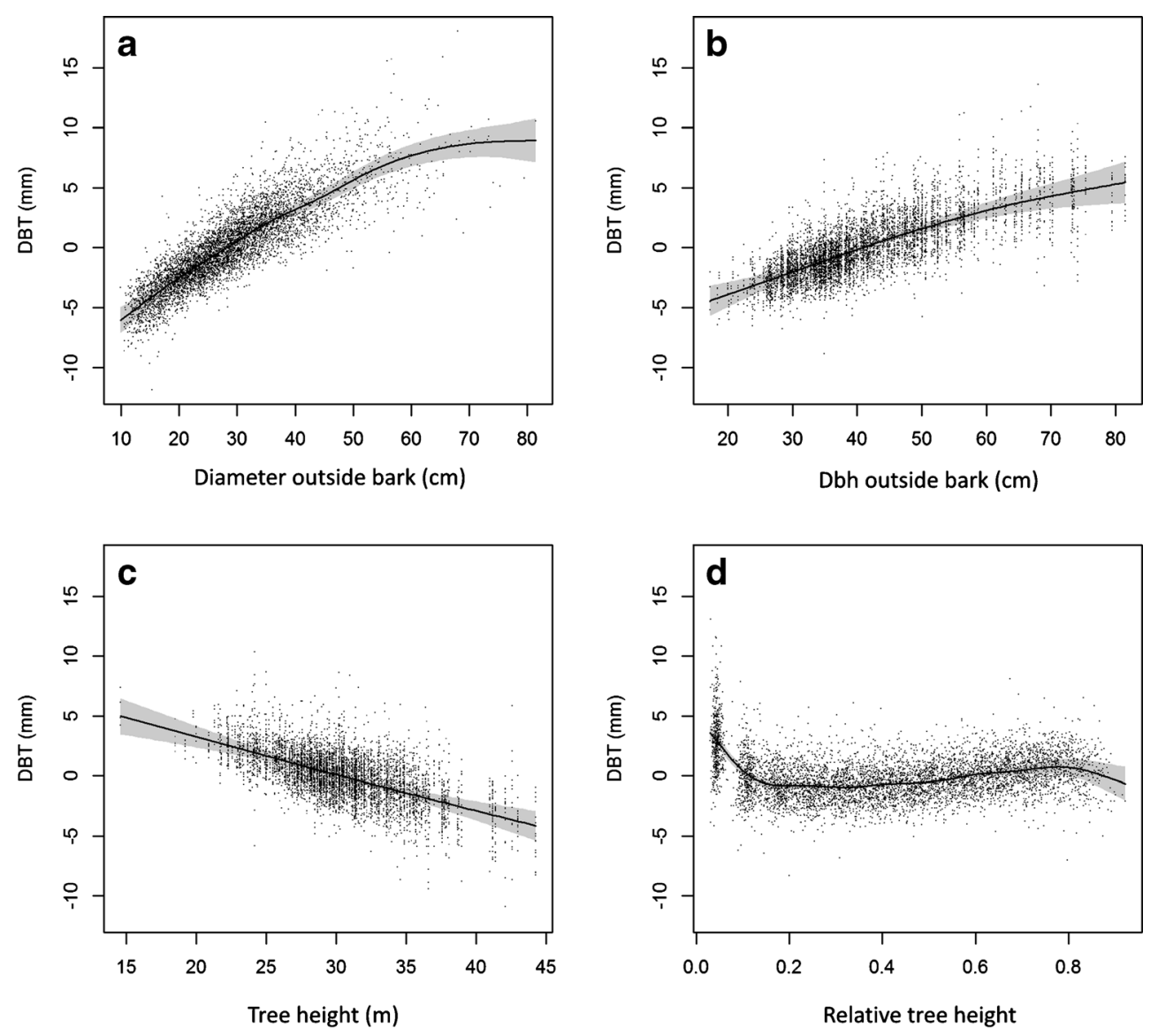

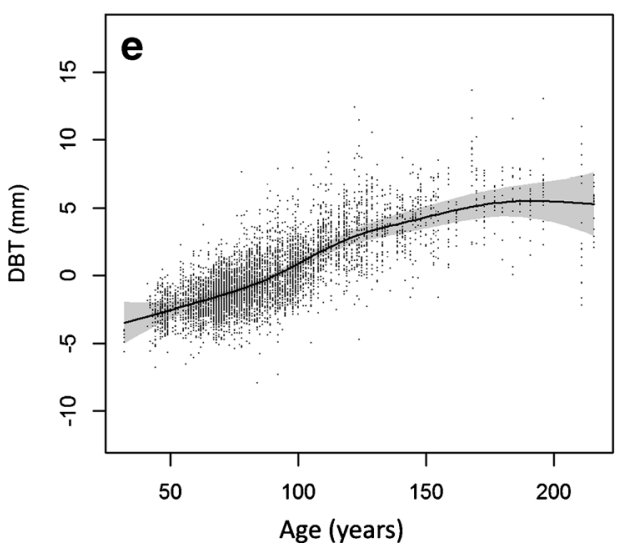

Vogt 1986). Also, Laasasenaho et al. (2005) found that parameters, which described the individual growth, could explain differences between climatic regions.

It seems that no single environmental variable, such as climate or geography, can explain differences in bark thickness, but only the combination of many factors, which influence the productivity of a stand and the growth of individual trees. For bark thickness studies in the future, the assessment of tree age or site index is, therefore, strongly recommended to consider the effects of factors such as nutrient and water availability, aspect, or stand density.
The effect, that faster-grown trees have a thinner bark, might explain the thicker bark in dataset 1 compared to the new data. Since growth of Norway spruce in southwestern Germany has accelerated in the twentieth century (Yue et al. 2011), it can be expected that the trees of the new dataset had grown faster than the trees of dataset 1, which were harvested about 40 years earlier. The same equations with the same combination of independent variables showed to best explain bark thickness variation in the two datasets. This leads to the conclusion that the general processes influencing bark thickness were not different in two studied time periods. 


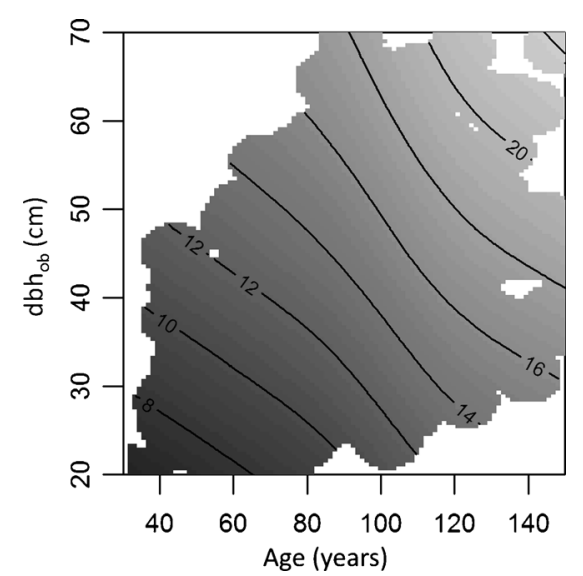

Fig. 4 Contour plot showing estimated double bark thickness in millimetres over age and breast height diameter outside bark $\left(\mathrm{dbh}_{\mathrm{ob}}\right)$. Covariates that were included in the model but are not shown were set to the median of occurring values in the data. Shaded area approximately covers the region that was covered by observations

Intraspecific bark thickness differences between sites could mainly have two physiological reasons: either differences in the cambial activity on the xylem and the phloem sides or differences in the activity ratio of cambium and phellogen. Phloem increment in Norway spruce seems to vary between sites (Gričar et al. 2015b) but is more stable and less subjected to fluctuations in environmental conditions than xylem increment (Gričar and Čufar 2008; Gričar et al. 2007; Prislan et al. 2013). However, phloem cells collapse within few years (Evert 2009) and total bark thickness is largely determined by the thickness of the rhytidome. Factors influencing rhytidome development are difficult to estimate as there is not yet much research done on the complex processes of cell collapse and simultaneous inflation of other cell types (Gričar et al. 2015a). We may speculate that the higher investment in bark of slower-growing trees is evolutionary adaptive, as slowergrown trees need more time to reach reproductive age and, therefore, have a higher risk of mechanical damage and exposure to radiation and extreme temperature or other factors that a thicker bark might protect them from.

\section{Conclusion}

With our analysis, we confirmed that bark thickness varies for Norway spruce between single trees and between groups of trees that were sampled in different sites. Models of different complexity can be suggested depending on the purpose of application. An increase in predictive accuracy can be obtained by using models with more predictor variables; however, this increases the costs for data acquisition. In our study, we could not gain convincing evidence for geospatial variation of bark thickness development within the study area. In the study region, the variation of site productivity and individual growth rate seem to have a strong influence on bark thickness, with better site quality leading to smaller relative bark thickness.

Acknowledgements The authors thank Aikaterini Nakou and Aaron Weiskittel for statistical advice and discussing the study design. Furthermore, we thank Franka Brüchert, Ulrich Kohnle, and Gerald Kändler for fruitful discussions in this project. We also thank three anonymous reviewers for helping to improve a prior version of this manuscript.

\section{Compliance with ethical standards}

Funding This study was funded by the Ministry for Rural Affairs and Consumer Protection Baden-Württemberg, Germany (MLR) and was conducted at the Forest Research Institute Baden-Württemberg (FVA).

\section{References}

Altherr E, Unfried P, Hradetzky J, Hradetzky V (1974) Statistische Rindenbeziehungen als Hilfsmittel zur Ausformung und Aufmessung unentrindeten Stammholzes: Teil I:Kiefer, Buche, Hainbuche, Esche und Roterle. Mitteilungen der Forstlichen Versuchs- und Forschungsanstalt, vol 61. Forstliche Versuchs- und Forschungsanstalt Baden-Württemberg, Freiburg im Breisgau

Altherr E, Unfried P, Hradetzky J, Hradetzky V (1978) Statistische Rindenbeziehungen als Hilfsmittel zur Ausformung und Aufmessung unentrindeten Stammholzes: Teil IV: Fichte, Tanne, Douglasie und Sitka-Fichte. Mitteilungen der Forstlichen Versuchs- und Forschungsanstalt, vol 90. Forstliche Versuchs- und Forschungsanstalt Baden-Württemberg, Freiburg im Breisgau

Barton K (2016) MuMIn: multi-model inference: R package version 1.15 .6

Baskerville GL (1972) Use of logarithmic regression in the estimation of plant biomass. Can J For Res 2:49-53

Božić M, Čavlović J, Vedriš M, Jazbec M (2007) Modeling bark thickness of silver fir trees (Abies alba Mill.). Šumarski list 131:3-12

Cao QV, Pepper WD (1986) Predicting inside bark diameter for shortleaf, loblolly, and longleaf pines. South J Appl For 10:220-224

Cellini JM, Galarza M, Burns SL, Martinez-Pastur GJ, Lencinas MV (2012) Equations of bark thickness and volume profiles at different heights with easy-measurement variables. Forest Sys 21. doi:10.5424/fs/2112211-01963

Dimitrov ET (1976) Mathematical models for determining the bark volume of spruce in relation to certain mensurational characteristics (translated from Hungarian). Gorstoskopanska Nauka (Forest Science) 13:52-63

Doruska PF, Patterson D, Hartley J, Hurd M, Hart T (2009) Newer technologies and bioenergy bring focus back to bark factor equations. J For 107:38-43

Evert RF (2009) Esaus Pflanzenanatomie: Meristeme, Zellen und Gewebe der Pflanzen - ihre Struktur, Funktion und Entwicklung. Walter de Gruyter, Berlin

Flury P (1897) Einfluss der Berindung auf die Kubirung [sic!] des Schaftholzes. In: Bourgeois C (ed) Mitteilungen der Schweizerischen Centralanstalt für das forstliche Versuchswesen, vol 5. Fäsi \& Beer, Zürich, pp 203-255

Gordon A (1983) Estimating bark thickness of Pinus radiata. New Zeal J For Sci 13:340-348

Gray, H.R. 1956 The form and taper of forest-tree stems. Imperial Forestry Institute, Universtity of Oxford 
Gričar J, Čufar K (2008) Seasonal dynamics of phloem and xylem formation in silver fir and Norway spruce as affected by drought. Russ J Plant Physl 55:538-543. doi:10.1134/s102144370804016x

Gričar J, Zupančič M, Čufar K, Oven P (2007) Regular cambial activity and xylem and phloem formation in locally heated and cooled stem portions of Norway spruce. Wood Sci Technol 41:463-475. doi:10.1007/s00226-006-0109-2

Gričar J, Jagodic Š, Prislan P (2015a) Structure and subsequent seasonal changes in the bark of sessile oak (Quercus petraea). Trees 29:747757

Gričar J, Prislan P, De Luis M, Gryc V, Hacurová J, Vavrčík H, Čufar K (2015b) Plasticity in variation of xylem and phloem cell characteristics of Norway spruce under different local conditions. Frontiers in plant science 6

Hannrup B (2004) Funktioner för skattning av barkens tjocklek hos tall och gran vid avverkning med skördare (Functions for prediction of bark thickness of Norway spruce and Scots pine at CTL-harvesting). Arbetsrapport 575. Skogforsk, Uppsala

Hoffmann J (1958) Untersuchungen über die Rindenstärke der Fichte auf verschiedenen Standorten im südöstlichen Thüringer Wald. Wiss Z TU Dresden 7:361-368

Hosius B, Leinemann L, Konnert M, Bergmann F (2006) Genetic aspects of forestry in the central Europe. Europ J Forest Res 125:407-417. doi:10.1007/s10342-006-0136-4

Kohnle U, Hein S, Sorensen FC, Weiskittel AR (2012) Effects of seed source origin on bark thickness of Douglas-fir (Pseudotsuga menziesii) growing in southwestern Germany. Can J For Res 42: 382-399. doi:10.1139/X11-191

Konnert M (1991) Die Fichte (Picea abies [L.] Karst.) im Schwarzwald: Genetische Variation und Korrelationen. Forstw Cbl 110:84-94

Kublin, E. and Breidenbach, J. 2013 TapeR: flexible tree taper curves based on semiparametric mixed models: R package version 0.3.0

Laasasenaho J, Melkas T, Aldén S (2005) Modelling bark thickness of Picea abies with taper curves. For Ecol Manag 206:35-47. doi:10.1016/j.foreco.2004.10.058

Li R, Weiskittel AR (2011) Estimating and predicting bark thickness for seven conifer species in the Acadian region of North America using a mixed-effects modeling approach: comparison of model forms and subsampling strategies. Europ J Forest Res 130:219-233. doi:10.1007/s10342-010-0423-y

Loetsch F, Zöhrer F, Haller KE (1973) Forest inventory, vol 2. BLV Verl. Ges, München

Martin RE, Crist JB (1970) Elements of bark structure and terminology. Wood \& fiber 2:269-279

Mesavage C (1969) Measuring bark thickness. J For 67:753-754

Persson B, Downie B (1992) Variation in bark thickness of young Pinus contorta var. latifolia Engelm. in Sweden. Scand J For Res 7:99106. doi:10.1080/02827589209382701

Pinheiro JC, Bates DM (2000) Mixed-effects models in S and S-plus. Statistics and computing. Springer, New York
Pinheiro J, Bates D, DebRoy S, Sarkar D, R Core Team (2016) nlme: linear and nonlinear mixed effects models, version 3.1-124 edn

Prislan P, Gričar J, de Luis M, Smith KT, Čufar K (2013) Phenological variation in xylem and phloem formation in Fagus sylvatica from two contrasting sites. Agric For Meteorol 180:142-151. doi:10.1016 /j.agrformet.2013.06.001

R Core Team (2015) R: a language and environment for statistical computing. R Foundation for Statistical Computing, Vienna, Austria

Robinson AP (2016) Equivalence: provides tests and graphics for assessing tests of equivalence, 0.7.1 edn

Robinson AP, Froese RE (2004) Model validation using equivalence tests. Ecol Model 176:349-358. doi:10.1016/j.ecolmodel.2004.01.013

Schielzeth H, Nakagawa S (2013) Nested by design: model fitting and interpretation in a mixed model era. Methods Ecol Evol 4:14-24. doi:10.1111/j.2041-210x.2012.00251.x

Schmidt-Vogt H (1986) Die Fichte-Ein Handbuch in zwei Bänden, Band II/1: Wachstum, Züchtung, Boden, Umwelt, Holz. Parey, Hamburg und Berlin

Skogforsk (2012) Standard for forest data and communication. Appendix: definitions of variables - general and country specific. vol 2012-04-18. http://www.skogforsk.se/contentassets/b063 db555a664ff8b515ce121f4a42d1/appendix1_eng_120418.pdf. Accesed 27 June 2016.

Sonmez T, Keles S, Tilki F (2007) Effect of aspect, tree age and tree diameter on bark thickness of Picea orientalis. Scand J For Res 22:193-197. doi:10.1080/02827580701314716

Sprugel D (1983) Correcting for bias in log-transformed allometric equations. Ecology 64:209-210

Stängle SM, Weiskittel AR, Dormann CF, Brüchert F (2016) Measurement and prediction of bark thickness in Picea abies: assessment of accuracy, precision, and sample size requirements. Can J For Res 46:39-47. doi:10.1139/cjfr-2015-0263

Weiskittel AR, Hann DW, John A, Kershaw J, Vanclay JK (2011) Forest growth and yield modeling. Wiley, Hoboken, NJ

Wilhelmsson L, Arlinger J, Spångberg K, Lundqvist S-O, Grahn T, Hedenberg Ö, Olsson L (2002) Models for predicting wood properties in stems of Picea abies and Pinus sylvestris in Sweden. Scand J For Res 17:330-350. doi:10.1080/02827580260138080

Wood SN (2006) Generalized additive models: an introduction with R. $\mathrm{CRC}$ press

Wood SN (2011) Fast stable restricted maximum likelihood and marginal likelihood estimation of semiparametric generalized linear models. J Roy Stat Soc Ser B (Stat Method) 73:3-36. doi:10.1111/j.14679868.2010.00749.x

Yue C, Kohnle U, Hanewinkel M, Klädtke J (2011) Extracting environmentally driven growth trends from diameter increment series based on a multiplicative decomposition model. Can J For Res 41:15771589. doi:10.1139/x11-056

Zacco P (1974) Barktjockleken hos sågtimmer (The bark thickness of saw logs). Rapport, vol 90.The Swedish University of Agricultural Sciences, Department of Forest Products. Stockholm 